\title{
Does Upper Extremity Training Influence Body Composition after Spinal Cord Injury?
}

\author{
Justin A. Fisher ${ }^{1,2}$, Meredith A. McNelis ${ }^{1,2}$, Ashraf S. Gorgey ${ }^{1,3}$, \\ David R. Dolbow ${ }^{4}$, Lance L. Goetz ${ }^{1,3}$ \\ ${ }^{1}$ Spinal Cord Injury and Disorders Center, Hunter Holmes McGuire VAMC, Richmond, VA 23249, USA \\ ${ }^{2}$ Department of Health and Human Performance; Exercise Science; Virginia Commonwealth University \\ ${ }^{3}$ Department of Physical Medicine and Rehabilitation, Virginia Commonwealth University, Richmond, VA \\ 23249, USA \\ ${ }^{4}$ School of Human Performance and Recreation, University of Southern Mississippi, Hattiesburg, USA
}

[Received June 30, 2013; Revised September 6, 2014; Accepted September 12, 2014]

\begin{abstract}
Spinal cord injury (SCI) leads to serious body composition adaptations characterized by increasing whole body fat mass and decreased soft tissue lean mass (LM). These adaptations in body composition may lead to several cardio-metabolic disorders that reduce the quality of life, increase patients' and caregivers' burden and eventually leads to mortality. Exercise, an appropriate dietary regimen, and an active lifestyle may alleviate several of the negative effects on body composition after a SCI. Today however, there is no established consensus on the recommended dose, frequency or type of exercise to ameliorate several of the body composition sequelae after an acute SCI. Resistance training has been previously recommended as an effective strategy to restore soft tissue $L M$ and decrease fat mass (FM). The strategy can be simply implemented as a routine home-based training program using free weights or resistance bands after a SCI. Additionally, upper extremity (UE) circuit resistance training has been previously used to improve cardiovascular and metabolic parameters after a SCI; however compared to the vast knowledge regarding the able-bodied (AB) population, the effects of $\mathrm{UE}$ circuit resistance training on body composition after a SCI is not well established. In summary, the available evidence does not support the rationale that $\mathrm{UE}$ circuit resistance training can lead to positive adaptations in body composition after a SCI. Further studies are suggested to examine the effects of UE circuit resistance training on body composition.
\end{abstract}

Key words: spinal cord injury, body composition, cardio-metabolic factors, upper extremity, circuit resistance training, barriers to exercise, home-based training

\section{Body composition}

Body composition refers to the relative amount or percentage of different types of body tissue (bone, fat, muscle) that are related to health [1]. Body composition assessment involves the accurate measurement of one or many of the compartments of FM and fat free mass (FFM) [2]. The American College of Sports Medicine (ACSM) utilizes body composition expressed as a percentage of total body fat [1]. Body composition assessment techniques may include, but are not limited to, skinfold measurements, waist and abdominal circumferences, transverse and sagittal diameters, dual-energy X-ray absorptiometry (DXA) scans, bioelectrical impedance analysis (BIA), whole-body air displacement plethysmography "BOD POD"(R) and underwater (hydrostatic) weighing (UWW) [1,2]. In general, fat cells can be stored either subcutaneously or in non-adipose tissue sites, including bone, muscle, liver and other intraabdominal locations (especially mesentery). The storage of fat cells in non-subcutaneous sites is referred to as ectopic adipose tissue and is commonly associated with

*Correspondence should be addressed to: Dr. Ashraf S. Gorgey, Department of Veterans Affairs, Spinal Cord Injury \& Disorders Service, Richmond, VA 23249, USA. Email: ashraf.gorgey@va.gov 
increased risks of developing cardio-metabolic disorders. For example, trunk FM is compartmentalized into visceral adipose tissue (VAT) and subcutaneous adipose tissue (SAT). Increased VAT is independently associated with all-cause mortality in different clinical populations. The FFM compartment is comprised of LM, water $(\sim 73 \%)$ and bone. The FFM compartment has a greater metabolic activity compared to FM and tends to decline with age.

\section{Significance of measuring body composition}

There are many differences in body composition between individuals as a result of the interaction between genetics, physical activity, and nutritional habits $[3,4,5]$. Scientific evidence documents the importance of differences in body composition compartments with regard to morbidity and mortality [3]. Assessment of body composition optimizes the estimation of body energy status, the quantification of muscle mass, and the determination of the quantity and quality of bone [5]. Furthermore, it is significant in predicting several comorbidities such as cardiovascular disease, type II diabetes mellitus, disorders of the digestive system, and the overall nutritional status of an individual $[3,6,7]$. Body composition can also be used to determine the risk factors associated with obesity, physiological functions (cardiac output) and metabolic profile (rate of energy expenditure at rest and carbohydrate and lipid metabolism) [3]. The ACSM uses body mass index (BMI) values achieved by calculating the weight $(\mathrm{kg}) /$ height $^{2}\left(\mathrm{~m}^{2}\right)$ and uses waist girth to indicate obesity as a risk factor for atherosclerotic cardiovascular disease (CAD) [1]. Studying the adaptations in body composition may also reflect the level of physical activity, nutritional habits, and may identify risk of developing cardio-metabolic disorders. Body composition has been shown to be impacted by space flight missions, engagement in active lifestyles and sports, and after neurologic disorders such as SCI, stroke and cerebral palsy.

\section{Spinal cord injury and body composition}

After a SCI, the percentage of FM increases and is accompanied by significant reductions in soft tissue LM. Within a few weeks of injury, an individual with a SCI may lose approximately $30-60 \%$ of skeletal muscle size in both lower extremities $[4,8]$. They may also experience a continuous loss of LM in the trunk and arms after an acute SCI. These adaptations in body composition may lead to a marked loss of skeletal muscle and metabolic function, obesity, insulin resistance, glucose intolerance, type II diabetes mellitus, and bone loss below the level of injury [8]. Age and the duration of injury (DOI), and level and completeness of injury, impact body composition [4]. As age and DOI increase, lean tissue percent decreases and adipose tissue increases.

Reduced muscle mass and inactivity are assumed to be contributors to the high prevalence of insulin resistance and type II diabetes mellitus within the SCI population [6, $8,9]$. Many researchers have established that metabolic risk factors, including reduced levels of high density lipoprotein-cholesterol (HDL), glucose intolerance, and insulin resistance are common within SCI individuals [918]. Early after SCI, individuals with paraplegia and tetraplegia experience weight loss because of the rapid loss in lean body mass and failure to maintain adequate caloric intake [8, 18]. This is followed by a gradual increase in body weight in the form of increasing FM and expansion of adipose tissue accumulation into nonadipose sites which leads to ectopic adiposity $[8,12,18$, 19]. The increase in ectopic adiposity and bone marrow fat imposes significant health risks following SCI $[8,18,19,20]$. A recent cross-sectional study revealed that persons with chronic SCI had three times greater bone marrow fat than their matched AB individuals [20]. Body weight declines significantly during the first six months after SCI, with a profound loss in muscle and bone tissues and gains in adipose tissue $[8,18,21,22]$. Persons with SCI 10-21 years of age experience a decrease in lean tissue mass and bone mineral content with an increase in FM [23].

On the other hand, the increase in VAT is correlated with an increased risk of cardiovascular disease (CVD) and a greater occurrence of metabolic syndrome in both the AB and SCI populations [18, 19, 20,24]. Edwards et al. found that adults with chronic SCI have significantly more total adipose tissue, VAT and a higher VAT/SAT ratio than do $\mathrm{AB}$ adults [25]. The $\mathrm{AB}$ adults for this study were matched for age, sex, and waist circumference (WC). The results suggested that WC is highly correlated with VAT in persons with SCI. Those persons have $42 \%$ more VAT per centimeter $(\mathrm{cm})$ of $\mathrm{WC}$ than their $\mathrm{AB}$ counterparts and more than double (162\%) the amount of VAT per $\mathrm{cm}$ WC when adjusted for BMI and age [25]. Gorgey et al. found similar results with persons having an increase in whole body FM after SCI which diluted both VAT and SAT masses [19]. The VAT compartment represents $6-10 \%$ of total body FM, whereas abdominal SAT represents $10-13 \%$ of total body FM in individuals with chronic SCI [19, 25]. Furthermore, leg and trunk FM were shown to be associated with increasing cardiometabolic risk factors after a SCI [26].

After a SCI, soft tissue FM increases at an alarming rate and is associated with dyslipidemia, defects in carbohydrate metabolism, and possible development of CVD $[10,16,18]$. It has been found that a pro-thrombotic state and elevated levels of pro-inflammatory cytokines are present after SCI $[13,27,28]$. Together, these result 
in the clustering of cardiovascular risk factors defined as a metabolic syndrome, currently referred to as cardiometabolic syndrome [29]. Clustering refers to the distinct combinations of risk factors in populations that may convey health hazards [29]. However, cardio-metabolic syndrome is defined as the existence of three or more of the following: overweight/obesity, atherogenic dyslipidemia, hypertension, and insulin resistance [24, 30, 31]. Libin et al. in a study of 121 subjects with C5-T12 motor complete SCI, reported that $76.9 \%$ of the participants had the potential to develop risks for metabolic syndrome [29]. Those with paraplegia had a higher incidence of elevated systolic blood pressure, BMI, HDL, triglycerides (TG), and fasting insulin [29].

\section{Assessment of Body Composition}

BMI, waist and abdominal circumferences, and transverse and sagittal diameter measurements are useful techniques for indicating FM in both $\mathrm{AB}$ and SCI individuals. One of the most commonly used indicators of body composition is BMI. Although BMI is a good predictor of an individual's FM, it has been shown to underestimate the percentage of FM after SCI $[4,26]$. There is a need to establish BMI standards for the SCI population. This can be done by lowering the definition of the current World Health Organization (WHO) criteria. There is evidence to support that BMI close to $22 \mathrm{~kg} / \mathrm{m}^{2}$ can be used to identify overweight and obese individuals with SCI [32]. It has been suggested by Laughton et al. to modify the SCI BMI ranges to $22-25 \mathrm{~kg} / \mathrm{m}^{2}$ for overweight and $\geq 25 \mathrm{~kg} / \mathrm{m}^{2}$ for obese individuals [32]. Waist and abdominal circumferences are also valid measurements that can be used for the assessment of obesity and identifying those with potential cardio-metabolic risk factors $[16,18]$. To obtain circumference and waist measurements for an individual with a SCI most accurately, participants should be measured sitting up or lying supine [33]. Research is currently underway to determine the range of waist and abdominal circumferences that may identify those with SCI having FM greater than 30\%, as developing abnormal carbohydrate and lipid metabolisms in the future is likely [18].

Different body composition assessment techniques have been utilized following SCI. Previously, UWW has been considered a "gold standard" for body fat percentage assessments after SCI. However, it has many disadvantages, such as being impractical in clinical settings [34], difficulty encountering measuring residual lung volume, time consuming [35], and labor intensive [33]. UWW involves difficult maneuvers such as holding one's breath underwater and is highly reliant on participant performance. Computerized tomography (CT) and magnetic resonance imaging (MRI) have also been considered to be the "gold standard" methods for measuring VAT, SAT, skeletal muscle size, and intramuscular adipose tissue [12, 19, 25]. Moreover, ultrasound imaging techniques have evolved as an important tool that can be used to measure skeletal muscle cross-sectional areas, VAT thickness as well as blood flow in persons with SCI [36-38]. These measurements have the capability to precisely measure fat crosssectional areas or volume in regional compartments, including the abdominal region $[36,38]$. These techniques demonstrate high precision in measuring the regions of interest and appear to be highly reliable [37]. However, the cost of both CT and MRI scans are high, and special training is required for image analysis [12, 19, 25]. Therefore, DXA is commonly used to measure total and regional body composition, including measures of bone mineral content, bone mineral density and soft tissue LM and FM [4, 19, 23, 39]. DXA has been proposed as a suitable alternative for measuring abdominal adiposity since it is relatively inexpensive, rapid to perform and requires minimal cooperation from the individual. The use of DXA for evaluation of trunk FM and its relevance to visceral adiposity has yet to be investigated in persons with SCI.

Exercise and healthy dietary habits may result in lowering the percentage of FM and reduce the associated co-morbidities after SCI [39-41]. However, the elderly and individuals with high level SCI are physically disabled and may have difficulty exercising or accessing an exercise facility. The majority of individuals with SCI have difficulty engaging in effective exercise programs that result in improvements in health related variables. Paralysis or weakness of major muscle groups pertaining to grasping or lifting may hinder the effectiveness of any exercise trial. A person with a C5 motor complete SCI may have very limited capacity to functionally utilize the upper extremities to effectively engage in a daily exercise routine. They may also lack access to appropriate dietary guidelines after a SCI [40]. A standard healthy diet largely impacts an individual's body composition, but is most effective when it is combined with exercise [40].

\section{Definitions of Exercise}

Exercise is a vital component in maintaining cardiovascular and muscular health among individuals of different age groups and with different clinical populations. The ACSM, refers to exercise as "a type of physical activity consisting of planned, structured, and repetitive bodily movements done to improve and/or maintain one or more components of physical fitness" [1]. The Oxford Dictionary refers to exercise as a term describing any activity requiring physical effort, carried out to sustain or improve health and fitness 
(www.oxforddictionaries.com/us/definition/american_en glish/exercise?q=exercise). During exercise the body uses energy which results in the expenditure of calories. The energy that is expended during exercise is beneficial to the human body in many different ways due to an elevation in energy expenditure post exercise and an increase in resting metabolic rate (RMR). This results in an increased use of energy post exercise and at rest [42].

According to the ACSM, adequate cardiorespiratory exercise should consist of at least one hundred-fifty minutes per week of moderate intensity activity or seventy-five minutes of high intensity activity in order to improve the cardiorespiratory system [1]. The ACSM also suggests resistance training two to three days per week, in order to improve muscular fitness [1]. Specific exercise recommendations have been developed for individuals experiencing disabling physical conditions. It is suggested that persons with SCI follow the recommendations for the average individual [1]. Another leading organization, SCI Action Canada, provides recommendations for exercise prescription. These guidelines include aerobic activity two times per week for at least twenty minutes and resistance training two times per week for one set of eight to ten repetitions (www.sciactioncanada.ca/docs/ guidelines/Physical-Activity-Guidelines-for-Adults witha-Spinal-Cord-Injury-Health-Care-Professional.pdf).

\section{Types of Exercise and Benefits for Individuals with SCI}

There are many different forms of exercise including UE circuit resistance training, endurance training, locomotor training and electrical stimulation in which an individual with SCI can participate. These types of exercises have an emphasis on increasing cardiovascular and upper/lower extremity muscular fitness. Studies have utilized neuromuscular electrical stimulation or functional electrical stimulation (FES) to exercise lower extremity muscles to reverse the process of rapid skeletal muscle atrophy or regress bone loss in the paralyzed lower extremities [41-45]. Because of limitations in movement of the lower extremities, FES is conducted by sending an electrical current to the nerves of specific paralyzed muscles, which results in muscle contraction [43-45]. FES has been shown to increase soft tissue LM, muscular strength, and improve cardiovascular fitness [43, 45]. Although the benefits of FES are well established, accessibility to FES devices is often limited to medical centers or highly specialized centers with a rehabilitation unit. Efforts have been made to develop a home based training protocol using electrical stimulation units [44, 45]. Insurance companies often require medical justification and may not approve the purchase of the equipment due to expenses or injuries that may result.
Therefore, it is important to emphasize that UE training may need to be more accessible for the overall well-being and quality of life in individuals with SCI. This type of training can be completed at home with the use of free weights, resistance bands or medicine balls. These are more accessible strategies for persons with SCI, especially those in rural-areas.

A major research question of interest is whether there is evidence to support that UE resistance training or circuit resistance training may lead to improvements in body composition variables. Improvement in body composition variables can lead to improvement in cardio-metabolic health after SCI. The significance of the current review may rely on the fact that circuit resistance training can be prescribed as a home based exercise program, which may lead to subsequent improvements in other health variables.

\section{Exercise and Body composition}

Several exercise trials have proven effective in alleviating the effects of SCI on body composition. Griffin et al. found that 10 weeks of FES cycling increased soft tissue LM by $4 \%$ [46], whereas Hjeltnes et al. found a $2 \%$ increase in whole body LM after only 8 weeks [47]. Skold et al. found a $10 \%$ increase in muscle tissue volume after 6 months of FES cycling [48]. Although soft tissue LM was altered, after 10 weeks of FES cycling, the overall total body adipose tissue was not significantly affected [46]. Twelve weeks of progressive lower extremity resistance training evoked by surface neuromuscular electrical stimulation demonstrated muscle hypertrophy and improved regional body composition, (decreased central adiposity and intramuscular fat) in men with SCI [41]. Ryan et al. found that although muscle mass increased after 16 weeks of FES induced resistance training, intramuscular fat did not decrease [49]. Despite these findings, there is still not enough evidence to confirm the effects of UE resistance training on body composition [50].

\section{Effects of Upper Extremity Resistance Training on Body Composition in Able-Bodied Persons}

Recent studies among $\mathrm{AB}$ populations have provided sufficient evidence that resistance training has shown improvements not only in muscular strength and cardiorespiratory fitness, but also in body composition. Cullinen et al. presented data showing that after the completion of a 12 week resistance training program, healthy young women were able to increase soft tissue LM while achieving a lower body fat percentage [51]. A similar study conducted on both males and females demonstrated an increase in soft tissue LM with a 
decrease in body fat percentage after 10 weeks despite no significant change in overall weight [51]. This gives rise to the question of whether or not UE circuit resistance training provides improvements not just in overall functional capacity in individuals with a SCI but also in body composition. An observation that supports this hypothesis is that persons with paraplegia have greater fore-arm extensor cross-sectional area compared to $\mathrm{AB}$ controls and persons with tetraplegia [37].

Table 1. A list of studies that have used circuit resistance training (CRT) on different health variables after SCI.

\begin{tabular}{|c|c|c|c|c|c|}
\hline Reference & Participants & Methods & CRT Program & Results & Conclusion \\
\hline $\begin{array}{l}\text { Jacobs, P. L et } \\
\text { al. 2001[52] }\end{array}$ & $\begin{array}{l}\text { - } 10 \text { male } \\
\text { subjects, age } 28 \\
-44 \text { years old } \\
\text { - } \mathrm{SCI} \text { at } \mathrm{T}_{5}-\mathrm{L}_{1}\end{array}$ & $\begin{array}{l}\text { - Cardiorespiratory } \\
\text { Training } \\
\text { - Resistance Training for } \\
12 \text { weeks. Completed } 10 \\
\text { repetitions }\end{array}$ & $\begin{array}{l}\text { - Military Press } \\
\text { - Horizontal Rows } \\
\text { - Pec. Deck } \\
\text { - Preacher Curls } \\
\text { - Wide Grip } \\
\text {-Lat. Pull down } \\
\text { - Seated Dips }\end{array}$ & $\begin{array}{l}\text { - Increase in } \mathrm{VO}_{2} \text { peak } \\
\text { by } 29.7 \% \\
\text { - } 21 \% \text { increase in } \\
\text { muscular strength }\end{array}$ & $\begin{array}{l}\text { - } \uparrow \text { Cardiorespiratory } \\
\text { and Muscular fitness } \\
\text { due to upper } \\
\text { extremity circuit } \\
\text { training } \\
\text { - No report of changes } \\
\text { in body composition } \\
\text { was found }\end{array}$ \\
\hline $\begin{array}{l}\text { Hicks et al. } \\
2003[53]\end{array}$ & $\begin{array}{l}\text { - } 34 \text { men and } \\
\text { women with } \\
\text { SCI. } \\
\text { - 19-65 years old } \\
\text { - C4- L1, AIS A- } \\
\text { D. }\end{array}$ & $\begin{array}{l}\text { - } 9 \text { month study } \\
\text { - } 2 \text { session/ week } \\
\text { - 9- } 120 \text { minutes } \\
\text { - Resistance Training } \\
\text { included weight training } \\
\text { system } \\
\text { - Power Training } \\
\text { included 3, 5-7 min. } \\
\text { sessions of arm cranking }\end{array}$ & & $\begin{array}{l}\text { - Up to } 34 \% \\
\text { improvement in upper } \\
\text { body muscular strength } \\
\text { - Up to an } 81 \% \\
\text { increase in total power } \\
\text { output }\end{array}$ & $\begin{array}{l}\text { - } \uparrow \text { in upper extremity } \\
\text { muscular strength due } \\
\text { to circuit resistance } \\
\text { training } \\
\text { - No report of changes } \\
\text { in body composition } \\
\text { was found }\end{array}$ \\
\hline $\begin{array}{l}\text { Bizzarini et } \\
\text { al.2005 [54] }\end{array}$ & $\begin{array}{l}\text { - } 21 \text { subjects } \\
\text { with SCI } \\
\text { - 19-66 years } \\
\text { old } \\
\text {-C4-L2,AIS B,C. }\end{array}$ & $\begin{array}{l}\text { - } 5 \text { days/week for } 6 \\
\text { weeks. } \\
\text { - } 90 \mathrm{~min} / \text { day } \\
\text { - } 3 \text { sets/ } 8 \text { repetitions } \\
\text { - } 40 \%-60 \% 1 \mathrm{RM}\end{array}$ & $\begin{array}{l}\text { - Latissimus (lat.) Dorsi } \\
\text { - Deltiformis } \\
\text { - Pectoralis } \\
\text { - Triceps Brachii } \\
\text { - Biceps Brachii }\end{array}$ & $\begin{array}{l}-\uparrow \text { in workload (watts) } \\
\text { for all participants over } \\
6 \text { week period }\end{array}$ & $\begin{array}{l}\text { - No report of changes } \\
\text { in Body Composition }\end{array}$ \\
\hline $\begin{array}{l}\text { Durán et al. } \\
\text { 2001[55] } \\
15-38\end{array}$ & $\begin{array}{l}\text { - } 12 \text { men and } 1 \\
\text { woman with SCI } \\
\text { - 15-38 years old } \\
\text {-T3-T12, AIS A, } \\
\text { B, C }\end{array}$ & $\begin{array}{l}\text { - } 3 \text { sessions } \\
\text { - } 40 \mathrm{~min} / \text { day } \\
-120 \mathrm{~min} / \text { week } \\
\text { - } 16 \text { weeks } \\
-40 \%-80 \% \text { maximal } \\
\text { heart rate }\end{array}$ & $\begin{array}{l}\text { - Bench Press } \\
\text { - Military press } \\
\text { - Dumbbell (bicep) } \\
\text { - Dumbbell (tricep) } \\
\text { - Dumbbell (Shoulder } \\
\text { abductor) } \\
\text { - Butterfly Press } \\
\text { - Curl Back Neck }\end{array}$ & $\begin{array}{l}\text { - Significant } \% \\
\text { increase in weight }(\mathrm{kg}) \\
\text { and repetitions in } \\
\text { resistance exercise }\end{array}$ & $\begin{array}{l}\text { - Upper extremity } \\
\text { resistance training } \\
\text { was shown to } \\
\text { provide beneficial } \\
\text { increases to } \\
\text { muscular strength } \\
\text { and endurance }\end{array}$ \\
\hline
\end{tabular}




\begin{tabular}{|c|c|c|c|c|c|}
\hline $\begin{array}{l}\text { Nash M, } \\
2007[60]\end{array}$ & $\begin{array}{l}7 \text { Healthy Men } \\
-39-58 \text { years } \\
\text { old } \\
\text { - complete } \\
\text { paraplegia } \\
\text {-T5-T12 }\end{array}$ & $\begin{array}{l}40-45 \text { min sessions } \\
-3 \text { times/ week } \\
-16 \text { weeks } \\
-50-60 \% 1 \mathrm{RM}\end{array}$ & $\begin{array}{l}\text { - Overhead Press } \\
\text { - Horizontal Row } \\
\text { - Horizontal Butterfly } \\
\text { - Bicep Curl } \\
\text { - Lat. Pull down } \\
\text { - Triceps Press }\end{array}$ & $\begin{array}{l}-38.6 \% \uparrow \\
-59.7 \% \uparrow \\
-41.6 \% \uparrow \\
-41.4 \% \uparrow \\
-38.6 \% \hat{i} \\
-44.0 \% \hat{\imath}\end{array}$ & $\begin{array}{l}\text { CRT provides } \\
\text { favorable increases in } \\
\text { muscular strength in } \\
\text { individuals with SCI } \\
\text { - No report of changes } \\
\text { in body composition }\end{array}$ \\
\hline $\begin{array}{l}\text { Jacobs P.L., } \\
\text { 2009[61] }\end{array}$ & $\begin{array}{l}\text { - } 18 \text { subjects } \\
\text { - Complete } \\
\text { Paraplegia } \\
\text { - T6-T10 }\end{array}$ & $\begin{array}{l}\text { - } 3 \text { sessions/ week } \\
\text { - } 12 \text { weeks } \\
\text { - Endurance Training: } 30 \\
\text { minutes of arm crank at } \\
70-85 \% \text { HR(peak) } \\
\text { - Resistance Training: } 3 \\
\text { sets, } 10 \text { repetitions at } 6 \\
\text { exercise station. } 60-70 \% \\
1 \text { rep max. }\end{array}$ & $\begin{array}{l}\text { - Horizontal Press } \\
\text { - Horizontal Row } \\
\text { - Overhead Press } \\
\text { - Overhead Pull } \\
\text { - Seated Dips } \\
\text { - Arm Curls }\end{array}$ & $\begin{array}{l}\text { - } \mathrm{VO}_{2} \text { Peak increased } \\
\text { by } 15.1 \% \text { in } \mathrm{RT} \text { and } \\
11.8 \% \text { in } \\
\text { endurance training }\end{array}$ & $\begin{array}{l}\text { - } \uparrow \text { in upper extremity } \\
\text { strength, aerobic } \\
\text { capacity, muscular } \\
\text { strength and power by } \\
\text { participating in } \\
\text { resistance training } \\
\text { - No changes were } \\
\text { reported for body } \\
\text { composition }\end{array}$ \\
\hline $\begin{array}{l}\text { Sasso \& } \\
\text { Backus, } \\
\text { 2013[62] }\end{array}$ & $\begin{array}{l}\text { - } 1 \text { male with } \\
\text { T12 SCI } \\
\text { - } 44 \text { years old. }\end{array}$ & $\begin{array}{l}-3 / \text { days/week } \\
-12 \text { weeks } \\
-6 \text { UE exercises } \\
-3 \text { sets/ } 10 \text { reps } \\
-65 \%-75 \% \text { HRM } \\
- \text { Arm Crank } \\
-3 \text { minutes } \\
-65 \%-75 \% \text { HRM }\end{array}$ & $\begin{array}{l}\text { - Bicep Curls } \\
\text { - Seated Rows } \\
\text { - Wide Grip Lat. Pull } \\
\text { down } \\
\text { - Seated Dips } \\
\text { - Chest Fly } \\
\text { - Shoulder press } \\
\text { - } \begin{array}{l}\text { Rapid, low } \\
\text { intensity } \\
\text { endurance } \\
\text { exercise }\end{array}\end{array}$ & $\begin{array}{l}-14.3 \% \uparrow \text { in Lat. Pull } \\
\text { down } \\
\text { - } 13 \% \uparrow \text { in Bench press } \\
-6.4 \% \downarrow \text { in HR at } \\
\text { Anaerobic Threshold } \\
\text { - } 13.4 \% \uparrow \text { in } \\
\text { relative } \mathrm{VO}_{2} \\
\text { Peak }\end{array}$ & $\begin{array}{l}\text { - A } 12 \text { week, at home } \\
\text { exercise routine, was } \\
\text { shown to improve } \\
\text { cardiorespiratory and } \\
\text { muscular strength in } \\
\text { individuals with SCI }\end{array}$ \\
\hline
\end{tabular}



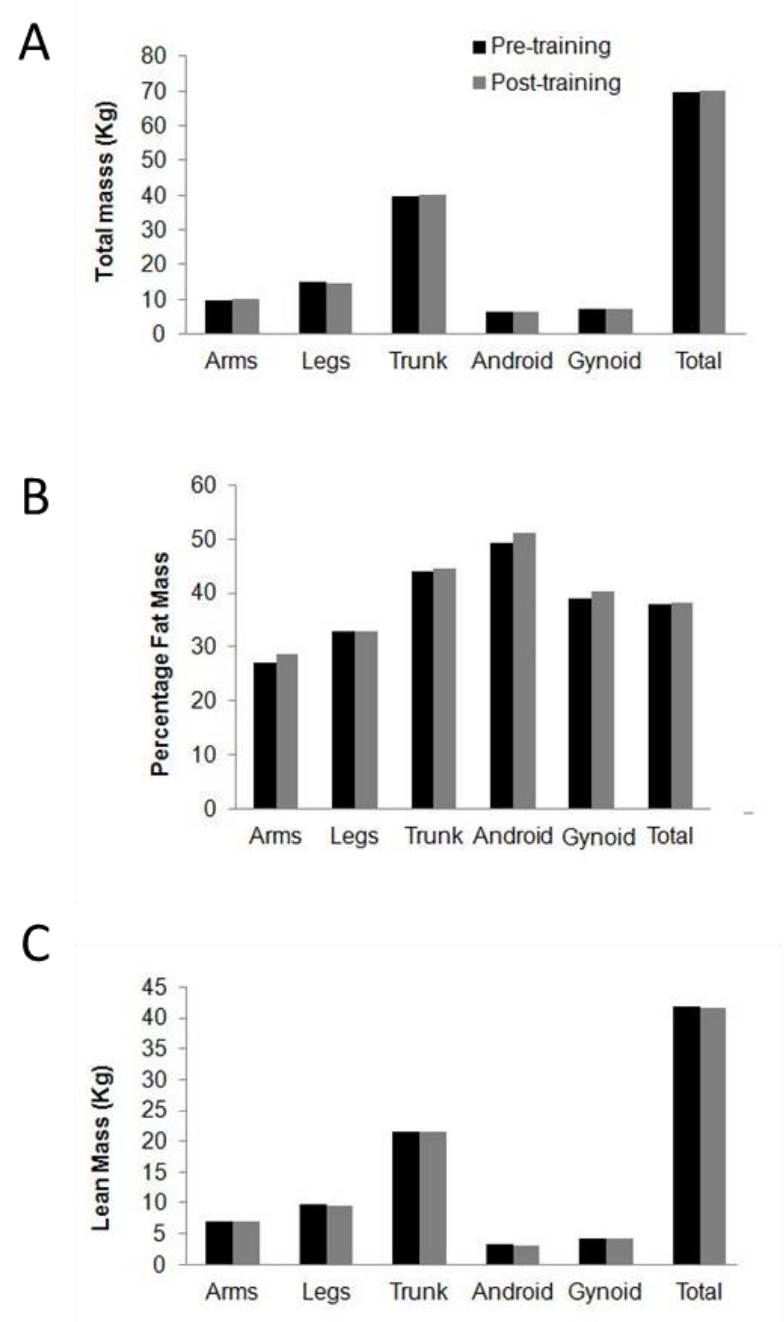

Figure 1. Body composition changes following UE resistance training. Changes in body composition in a person with T4 complete SCI including a) total body mass, b) percentage fat mass, c) lean mass as measured by DXA following 12 weeks of circuit resistance training that was conducted once weekly. The pre/post-training results suggested no changes in regional (arms, legs, trunk, android, gynoid) or total body composition.

\section{Upper Extremity Circuit Resistance Training in SCI Individuals}

UE circuit resistance training is an essential form of exercise for persons with SCI. It generally consists of a component involving weight training and a component of aerobic training $[52,53]$. The combination of both weight training and cardiovascular training, elicits encouraging changes in functional capacity, muscular strength and power.

A study conducted by Jacobs et al. showed that individuals with paraplegia were able to improve their UE endurance by $29.7 \%$ and muscle strength by up to $30 \%$ when completing a short bout circuit training exercise program for twelve weeks [52]. UE endurance and resistance training has been shown to improve power, muscular strength and peak oxygen uptake $\left(\right.$ peak $\left.\mathrm{VO}_{2}\right)$ for an individual with SCI [52]. The resistance program included three sets of ten repetitions on a six-exercise machine at $60-70 \%$ of one repetition maximum (RM) [52]. The endurance program included thirty minutes on an arm ergometer at $70-85 \%$ of heart rate (HR) peak [52]. It was concluded that the resistance training program showed greater improvements in UE aerobic capacity and in power and strength when compared to the endurance training program [52]. This suggests that when resistance and endurance training are performed simultaneously, many health benefits are accomplished to persons with SCI [52]. However, the study did not report any adaptations in body composition after a SCI.

A similar study found that individuals who participated in a program which consisted of exercising two times per week for nine weeks, showed significant improvements of up to $34 \%$ in upper extremity muscular strength and an increase of $81 \%$ in submaximal arm ergometer power output compared to a control group that did not participate in exercise. This study also indicated a positive correlation between exercise and quality of life [53]. It has been shown that UE exercise does in fact provide benefits for cardiovascular and muscular fitness. It is also important to know, to what extent, UE resistance circuit training has an impact on body composition in persons with a SCI. Table 1 presents a list of studies that have used UE circuit resistance training programs after a SCI. Based on the results of seven studies, there is no evidence to support changes in body composition following UE circuit resistance training.

\section{Exercise Prescription for SCI}

Despite the variety of modes of exercise training that can be provided, there is no established consensus on the optimum exercise intensity, frequency or duration for SCI individuals in order to improve specific health parameters. Exercise programs for persons with a SCI should be customized based on the severity, level of injury and the age of the participants. This creates a great challenge for an exercise specialist to identify a homogeneous cohort that will benefit from a specific exercise program. Most existing trials are considered underpowered because of small sample sizes and the heterogeneity of the studied population. However, some studies have presented information regarding different durations for an SCI exercise program based on the data collected. A study conducted by Bizzarini et al. found that after four to six weeks of exercise the participants began to plateau and 
their cardiovascular and muscular improvements became steady [54]. Therefore, for an individual with a SCI to enhance his/her functional capacity, a modification to the exercise program is necessary. The resistance training exercises performed in the study were conducted at an intensity of $40 \%-60 \%$ of their one RM. The aerobic training exercises were performed between $70-80 \%$ of maximum heart rate. Durán et al. found that sixteen weeks of an upper body aerobic resistance training program in individuals with T3-T12 SCI, with a frequency of three times per week for a total of one-hundred and twenty minutes resulted in increased UE muscular strength [55].

Clinical observations in our laboratory have found that UE resistance training exercise for twelve weeks, once per week, has resulted in a $60-320 \%$ increase in muscular strength for different muscle groups. Because the primary interest of the current review is to summarize the available evidence about the efficacy of UE resistance training on body composition, we have presented a DXA body composition assessment for an individual with T4 complete with an American Spinal Injury Association Impairment Scale (AIS) " $A$ " who engaged in 12 weeks of supervised UE circuit resistance training. The individual completed a 10-15 minute warm-up on arm-crank ergometer at 50 revolution per minute. This was followed by 45-60 minutes of exercise each session. The results of the 12 week clinical program suggest that participating in UE circuit resistance training once a week was not sufficient enough to evoke positive body composition changes in this individual (Figure 1). However, it is well recognized that persons with SCI continue to lose LM at higher rate that their age matched individuals with aging with subsequent increase in FM. The results of this single clinical case report may suggest that maintenance of total and regional LM may be achieved using UE circuit resistance training.

Although many studies have explored the effects of physical exercise and its associated benefits for individuals with SCI, there are still no definitive prescriptions with specific durations, intensities and exercises that can be used to improve body composition after SCI. However, it can be assumed that an UE circuit resistance training prescription that lasts between six to twelve weeks using ten to twelve repetitions can have an impact on functional capacity and strength, but not on body composition [56, Table 1]

\section{Barriers to Exercise in SCI}

The interest in advocating for UE resistance training may stem from the barriers SCI individuals experience when involved in active lifestyle programs. Individuals with physical disabilities are far less likely to participate in exercise than the average $A B$ individual. A survey reported that out of seventy-two individuals with SCI, 79.2\% believed exercise would be beneficial; however, only $45.8 \%$ had currently been involved in an exercise program [57]. This may be due to barriers to exercise encountered by individuals with SCI including transportation, financial and psychological barriers. The factors linked to exercise awareness and barriers following SCI have been recently highlighted [58].

Individuals with SCI may find it challenging and costly to obtain specialized transportation to and from exercise facilities. Furthermore, persons with SCI have reported issues within exercise facilities, including the lack of space between equipment for wheelchairs and poor maintenance and availability of equipment. In addition, individuals with SCI may need assistance with certain exercises that involve reaching, pulling or pushing weights. Individuals may have limited movement and strength in the forearm and hand muscles, resulting in the inability to adequately grip equipment. In order to resolve this barrier, persons with a SCI may need to utilize special wrist cuffs to enhance the grip on equipment to allow for the proper motion and contractions of an exercise. Without the assistance of other individuals or accessories, such as wrist cuffs, individuals with a SCI may not be able to perform beneficial training to increase UE muscular strength or endurance. It was also found that persons with a SCI do not participate in exercise because of emotional or psychological barriers. These emotional/psychological barriers include lack of motivation, needing assistance and fear of a new environment [59].

\section{Conclusion}

Significant body composition changes commonly occur after SCI characterized by decreased soft tissue LM, increased FM and ectopic adipose tissue. These negative adaptations have cardio-metabolic implications and lead to an increased prevalence of cardiovascular disorder after SCI. Physical and psychological barriers of exercise among individuals with SCI do exist. The prevalence of a sedentary lifestyle is very common and leading to an increased risk of health related medical co-morbidities. A home-based training program may be an effective strategy to overcome these barriers. Using UE resistance training may be a simple method to overcome body composition adaptations after SCI. Available evidence suggests improvements in overall functional capacity, muscular endurance, power and strength can occur with UE resistance circuit training after SCI. However, there is a lack of evidence supporting the benefits of UE resistance circuit training on body composition. Therefore, further studies are warranted to investigate the effects of UE circuit resistance training on body composition after a SCI. 


\section{Acknowledgements}

We would like to thank Hunter Holmes McGuire Research Institute and Spinal Cord Injury Services and Disorders for providing the environment to conduct clinical human research trials. Ashraf S. Gorgey is currently supported by the Department of Veteran Affairs, Veteran Health Administration, Rehabilitation Research and Development Service (B7867-W).

\section{References}

[1] Thompson WR, Gordon NF, Pescatello LS, ed (2010). ACSM's Guidelines for Exercise Testing and Prescription. 9th ed. Philadelphia, PA: Wolters Kluwer/Lippincott Williams \& Wilkins.

[2] Beechy L, Galpern J, Petrone A, Das SK (2012). Assessment tools in obesity - psychological measures, diet, activity, and body composition. Physiol Behav, 107: 154-71.

[3] Brožek, J (1961). Body Composition. Science, 134: 920-930.

[4] Spungen AM, Adkins RH, Stewart CA, Wang J, Pierson RN Jr, Waters RL, Bauman WA (2003). Factors influencing body composition in persons with spinal cord injury: a cross-sectional study. J Appl Physiol, 95: 2398-2407.

[5] Lohman, TG (1993). Advances in Body Composition Assessment. Medicine \& Science in Sports \& Exercise, 25, 762 .

[6] Davies PS (1993). Body composition assessment. Arch Dis Child, 69: 337-338.

[7] Kostovski E, Iversen PO, Hjeltnes N (2010). Complications of chronic spinal cord injury. Tidsskr Nor Laegeforen, 130: 1242-5.

[8] Qin, WP, Bauman, WA, Cardozo, C (2011). Bone and muscle loss after spinal cord injury: organ interactions. Ann N Y Acad Sci, 1211: 66-84.

[9] Bauman WA, Spungen AM, Raza M, Rothstein J, Zhang RL, Zhong YG, Tsuruta M, Shahidi R, Pierson RN, Wang J (1992). Coronary artery disease: metabolic risk factors and latent disease in individuals with paraplegia. Mt Sinai J Med, 59: 163-8.

[10] Bauman WA, Spungen AM (1994). Disorders of carbohydrate and lipid metabolism in veterans with paraplegia or quadriplegia: a model of premature aging. Metabolism, 43:749-56.

[11] Demirel S, Demirel G, Tukek T, Erk O, Yilmaz H (2001). Risk factors for coronary heart disease in patients with spinal cord injury in Turkey. Spinal Cord, 39: 134-8.

[12] Elder CP, Apple DF, Bickel CS, Meyer RA, Dudley GA (2004). Intramuscular fat and glucose tolerance after spinal cord injury - a cross-sectional study. Spinal Cord, 42: 711-6.

[13] Frost F, Roach MJ, Kushner I, Schreiber P (2005). Inflammatory C-reactive protein and cytokine levels in asymptomatic people with chronic spinal cord injury. Arch Phys Med Rehabil, 86: 312-7.

[14] Jones LM, Legge M, Goulding A (2004). Factor analysis of the metabolic syndrome in spinal cord-injured men. Metabolism, 53: 1372-7.

[15] Lee MY, Myers J, Hayes A, Madan S, Froelicher VF, Perkash I, Kiratli BJ (2005). C-reactive protein, metabolic syndrome, and insulin resistance in individuals with spinal cord injury. J Spinal Cord Med, 28:20-25.

[16] Maki KC, Briones ER, Langbein WE, Inman-Felton A, Nemchausky B, Welch M, Burton J (1995). Associations between serum lipids and indicators of adiposity in men with spinal cord injury. Paraplegia, 33: 102-9.

[17] Zlotolow SP, Levy E, Bauman WA (1992). The serum lipoprotein profile in veterans with paraplegia: the relationship to nutritional factors and body mass index. J Am Paraplegia Soc, 15: 158-62.

[18] Gate DR, Jr (2007). Obesity after spinal cord injury. Phys Med Rehabil N Am, 18:333-351.

[19] Gorgey AS, Mather KJ, Poarch H, Gater DR (2011). Influence of motor complete spinal cord injury on visceral and subcutaneous adipose tissue measured by multi-axial magnetic resonance imaging. J Spinal Cord Med, 34: 99-109.

[20] Gorgey AS, Poarch HJ, Adler RA, Khalil RE, Gater DR (2013). Femoral bone marrow adiposity and cortical bone cross-sectional areas in men with motor complete spinal cord injury. PM R, 5:939-48.

[21] Baldi JC, Jackson RD, Moraille R\& Mysiw WJ (1998). Muscle atrophy is prevented in patients with acute spinal cord injury using functional electrical stimulation. Spinal Cord, 36:463-469.

[22] Castro, MJ, Apple DF, Jr., Rogers S \& Dudley GA (2000). Influence of complete spinal cord injury on skeletal muscle mechanics within the first 6 months of injury. Eur. J. Appl. Physiol, 81: 128-13.

[23] McDonald CM, Abresch-Meyer AL, Nelson MD, Widman LM (2007). Body mass index and body composition measures by dual $\mathrm{x}$-ray absorptiometry in patients aged 10 to 21 years with spinal cord injury. J. Spinal Cord Med, 30: S97-S104.

[24] Abate N, Garg A, Peshock RM, Stray-Gundersen J, Grundy SM (1995). Relationships of generalized and regional adiposity to insulin sensitivity in men. J Clin Invest, 34: 53-70.

[25] Edwards LA, Bugaresti JM, Buchholz AC (2008). Visceral adipose tissue and the ratio of visceral to subcutaneous adipose tissue are greater in adults with than in those without spinal cord injury, despite matching waist circumferences. Am J Clin Nutr, 87: 600-607.

[26] Gorgey AS, Gater DR (2011). Regional and relative adiposity patterns in relation to carbohydrate and lipid metabolism in men with spinal cord injury. Appl Physiol Nutr Metab, 36: 107-114.

[27] Liang H, Mojtahedi MC, Chen D, Braunschweig CL (2008). Elevated C-reactive protein associated with 
decreased high-density lipoprotein cholesterol in men with spinal cord injury. Arch Phys Med Rehabil, 89: 3641.

[28] Wang TD, Wang YH, Huang TS, Su TC, Pan SL, Chen SY (2007). Circulating levels of markers of inflammation and endothelial activation are increased in men with chronic spinal cord injury. J Formos Med Assoc, 106: 919-928.

[29] Libin A, Tinsley EA, Nash MS, Mendez AJ, Burns P, Elrod M, Hamm LF, Groah SL (2013). Cardiometabolic risk clustering in spinal cord injury: results of exploratory factor analysis. Top Spinal Cord Inj Rehabil, 19: 183-94.

[30] Ford ES, Giles WH, Dietz WH (2002). Prevalence of the metabolic syndrome among US adults: Findings from the third National Health and Nutrition Examination Survey. JAMA, 287: 356-359.

[31] Haffner SM (2000). Obesity and the metabolic syndrome: The San Antonio Heart Study. Br J Nutr, 83: S67-S70.

[32] Laughton GE, Buchholz AC, Martin Ginis KA, Goy RE, SHAPE SCI Research Group (2009). Lowering body mass index cutoffs better identifies obese persons with spinal cord injury. Spinal Cord, 47: 757-762.

[33] Duren DL, Sherwood RJ, Czerwinski SA, Lee M, Choh AC, Siervogel RM, Cameron Chumlea W (2008). Body composition methods: comparisons and interpretation. $\mathrm{J}$ Diabetes Sci Technol, 2: 1139-1146.

[34] Heath EM, Adams TD, Daines MM, Hunt SC (1998). Bioelectric impedance and hydrostatic weighing with and without head submersion in persons who are morbidly obese. J Am Diet Assoc, 98: 869-875.

[35] Petroni ML, Bertoli S, Maggioni M, Morini P, Battezzati A, Tagliaferri MA, Liuzzi A, Testolin G (2003). Feasibility of air plethysmography (BOD POD) in morbid obesity: a pilot study. Acta Diabetol, 40: S59S62.

[36] Ribeiro-Filho FF, Faria AN, Azjen S, Zanella M, Ferreira SR (2003). Methods of estimation of visceral fat: Advantages of ultrasonography. Obes Res, 11: 1488-1494.

[37] Gorgey AS, Timmons MK, Michener LA, Ericksen JJ, Gater DR (2014). Intra-rater reliability of ultrasound imaging of wrist extensor muscles in patients with tetraplegia. PM R, 6: 127-133.

[38] Emmons RR, Garber CE, Cirnigliaro CM, Kirshblum SC, Spungen AM, Bauman WA (2011). Assessment of measures for abdominal adiposity in persons with spinal cord injury. Ultrasound Med Biol, 37: 734-741.

[39] D'Oliveira GL, Figueiredo FA, Passos MC, Chain A, Bezerra FF, Koury JC (2014). Physical exercise is associated with better fat mass distribution and lower insulin resistance in spinal cord injured individuals. J Spinal Cord Med, 37: 79-84.

[40] Khalil RE, Gorgey AS, Janisko M, Dolbow DR, Moore JR, Gater DR (2013). The role of nutrition in health status after spinal cord injury. Aging Dis, 4: 14-22.

[41] Gorgey AS, Mather KJ, Cupp HR, Gater DR (2012). Effects of resistance training on adiposity and metabolism after spinal cord injury. Medicine \& Science in Sports \& Exercise, 44: 165-174.

[42] Melby C, Scholl C, Edwards G, Bullough R (1993). Effect of acute resistance exercise on post exercise energy expenditure and resting metabolic rate. Journal of Applied Physiology, 75: 1847-1853.

[43] Peckham PH, Knutson JS (2005). Functional electrical stimulation for neuromuscular application. Annual Review of Biomedical Engineering, 7: 327-360.

[44] Dolbow DR, Gorgey AS, Ketchum JM, Moore JR, Hackett LA, Gater DR (2012). Exercise adherence during home-based functional electrical stimulation cycling by individuals with spinal cord injury. Am J Phys Med Rehabil, 91:922-30.

[45] Dolbow DR, Gorgey AS, Gater DR, Moore JR (2014). Body composition changes after 12 months of FES cycling: case report of a 60-year-old female with paraplegia. Spinal Cord, 52 Suppl 1:S3-4

[46] Griffin L, Decker MJ, Hwang JY, Wang B, Kitchen K, Ding Z, Ivy JL (2009). Functional electrical stimulation cycling improves body composition, metabolic and neural factors in persons with spinal cord injury. Journal of Electromyography and Kinesiology, 19: 614-622.

[47] Hjeltnes N, Aksnes AK, Birkeland KI, Johansen J, Lannem A, Wallberg-Henriksson H (1997). Improved body composition after 8 wk of electrically stimulated leg cycling in tetraplegic patients. Am J Physiol, 273: R1072-R1079.

[48] Skold C, Lonn L, Harms-Ringdahl K, Hulting C, Levi R, Nash M, Seiger A (2002). Effects of functional electrical stimulation for six months on body composition and spasticity in motor complete tetraplegic spinal cordinjured individuals. J Rehabil Med, 34: 25-32.

[49] Ryan TE, Brizendine JT, Backus D, McCully KK (2013). Electrically induced resistance training in individuals with motor complete spinal cord injury. Arch Phys Med Rehabil, 94: 2166-2173.

[50] Hicks AL, Martin Ginis KA, Pelletier CA, Ditor DS, Foulon B, Wolfe DL (2011). The effects of exercise training on physical capacity, strength, body composition and functional performance among adults with spinal cord injury: a systematic review. Spinal Cord, 49:1103-1127.

[51] Cullinen K, Caldwell M (1998). Weight training increase fat-free mass and strength in untrained women. Journal of the American Dietetic Association, 98: 414418.

[52] Jacobs PL, Nash MS, Rusinowski JW (2001). Circuit Training provides cardiorespiratory and strength benefits in persons with paraplegia. Med and Sci in Sports Exerc, 33: 711-717.

[53] Hicks AL, Martin KA, Ditor DS, Latimer AE, Craven C, Bugaresti J, McCartney N (2003). Long-term exercise in persons with spinal cord injury: effects on strength, arm ergometer performance and psychological well-being. Spinal Cord, 41: 34-43.

[54] Bizzarini E, Saccavini M, Lipanje F, Magrin P, Malisan C, Zampa A (2005). Exercise prescription in subjects 
with spinal cord injuries. Archives of Physical Medicine and Rehabilitation, 86: 1170-1175.

[55] Durán F, Lugo L, Ramírez L, Eusse E (2001). Effects of an exercise program on the rehabilitation of patients with spinal cord injury. Archives of Physical Medicine and Rehabilitation, 82: 1349-1354.

[56] Jacobs PL, Nash MS (2004). Exercise recommendations for individuals with spinal cord injury. Sports Medicine, 34: 727-751.

[57] Scelza WM, Kalpakjian CZ, Zemper ED, Tate DG (2005). Perceived barriers to exercise in people with spinal cord injury. Am J Phys Med Rehabil, 84: 576583.

[58] Gorgey AS (2014). Exercise awareness and barriers after spinal cord injury. World J Orthop. 18; 5:158-62.
[59] Rimmer JH, Riley B, Wang E, Rauworth A, Jurkowski J (2004). Physical activity participation among persons with disabilities: Barriers and Facilitators. American Journal of Preventative Medicine, 26: 419-425.

[60] Nash M, Van de Ven I, van Elk N, Johnson B (2007). Effects of circuit resistance training on fitness attributes and upper-extremity pain in middle-aged men with paraplegia. Archives of Physical Medicine and Rehabilitation, 88: 70-75.

[61] Jacobs PL (2009). Effects of Resistance and endurance training in person with paraplegia. Medicine and Science in Sports Exercise. Med Sci Sports Exerc, 41: 992-997.

[62] Sasso E, Backus D (2013). Home-Based Circuit Resistance Training to Overcome Barriers to Exercise for People with Spinal Cord Injury: A Case Study. Journal of Neurologic Physical Therapy, 37: 65-71. 